\title{
Efektivitas Program Rehabilitasi Sosial Terhadap Gelandangan Dan Pengemis Di Balai Rehabilitasi Sosial Bina Karya Cisarua
}

\author{
${ }^{1}$ II Sumantri, ${ }^{2}$ Faizal Pikri, ${ }^{3}$ Muhammad Aldi Lubis \\ ${ }^{1}$ Administrasi Publik Fakultas Ilmu Sosial dan Ilmu Politik UIN Sunan Gunung Djati Bandung; \\ iisumantri73@gmail.com \\ ${ }^{2}$ Administrasi Publik Fakultas Ilmu Sosial dan Ilmu Politik UIN Sunan Gunung Djati Bandung; \\ faizalpikri@uinsgd.ac.id \\ ${ }^{3}$ Administrasi Publik Fakultas Ilmu Sosial dan Ilmu Politik UIN Sunan Gunung Djati Bandung; \\ aldymuhammad82@yahoo.co.id
}

\begin{abstract}
This study aims to determine the process of knowing the organization of homeless and beggar coaching by the Social Rehabilitation Office of West Java Province. In addition, it is also important to know the assistance process carried out by the Social Rehabilitation Office for homeless people who have participated in the rehabilitation program. The method used in this research is descriptive method with a qualitative approach. Descriptive method aims to describe or provide a complete picture of the effectiveness of the social rehabilitation program of the Bina Karya Social Rehabilitation Office. The results showed that in general the program of activities held at the Rehabilitation Office was very influential on the client, despite the slight changes experienced by the clients. Basically, of the many programs held at the hall, the most influencing of the lives of these clients is the skill activities.
\end{abstract}

Keywords: Public Policy, Effectiveness, Social Rehabilitation Program, Social Welfare.

\section{Pendahuluan}

Gelandangan dan pengemis merupakan salah satu permasalahan sosial yang dapat menjadi penghalang untuk kemajuan pembangunan nasional, yaitu upaya pemangkasan kemiskinan dan cara bagaimana dapat meningkatkan kualitas Sumber Daya Manusia. Gelandangan dan pengemis pada dasarnya ialah sekelompok orang yang digolongkan dalam keadaan yang kurang mampu, sehingga mereka berpindah dari desa ke kota untuk mencari kehidupan yang lebih baik. Berdasarkan Peraturan Pemerintah Nomor 31 tahun 1980 Tentang Penganggulangan Gelandangan Dan Pengemis Bab 1 Pasal 1 Ayat 1 dan 2, dijelaskan bahwa gelandangan merupakan sekelompok orang yang hidupnya tidak sesuai dengan aturan hidup dari kebanyakan manusia lainnya, seta tidak memiliki kediaman dan pekerjaan yang tetap di suatu daerah tertentu dan biasanya hidup merantau di tempat umum. Sedangkan pengemis merupakan sekelompok orang yang sumber penghasilannya adalah pemberian dari orang lain secara cuma-cuma di tempat umum dengan alasan-alasan yang membuat orang lain simpati padanya.

Gelandangan dan pengemis biasanya terdiri dari usia produktif, biasanya dengan dasar pendidikan serta skill yang rendah, sehingga mereka tidak memiliki daya saing serta sulit untuk bertahan di kehidupan yang keras ini. Dalam menjalani kehidupan dan penghidupan, mereka sudah tidak memperhatikan lagi aturan-aturan yang berlaku bahkan agama sehingga senantiasa 
menuntun mereka pada perilaku yang buruk yang berakibat pada terganggunya keamanan, ketertiban dan kenyamanan. Hal tersebut tentunya tidak dibenarkan, karena sudah ada peraturan perundang-undangan yang mengaturnya.

Kesejahteraan sosial merupakan sebuah sistem atau lembaga yang memberikan pelayanan sosial serta institusi yang dibangun untuk membantu individu maupun kelompok untuk menvapai hubungan baik secara personal maupun untuk mengembangkan suatu kemampuan dan kesejahteraan atau kebutuhan keluargan dan masyarakat semuanya berjalan dengan seimbang, pengetian itu dikemukakan oleh Fiendlander (1980:4).

Tujuan-fungsi dan timbulnya masalah kesejahteraan sosial (Nurdin,1990). Kesejahteraan sosial sebagai sistem mempunyai tujuan dan fungsi-fungsi, yaitu:

1) Tujuan kesejahteraan sosial

a) Kehidupan yang sejahtera dapat dikatakan tercapai jika standar kehidupan pokok seperti sandang, pangan dan papan serta hubungan sosialnya sudah dapat terlaksana dengan baik.

b) Penyesuaian diri yang baik daapt dicapai dengan cara menggali sumber daya dan mengembangkan taraf hidup yang memuaskan baik kepada masyarakayt maupun lingkungannya.

\section{2) Fungsi-fungsi kesejahteraan sosial}

Fungsi dari kesejahteraan sosial ialah mengelola adanya disfungsional. Fungsi kesejahteraan sosial pada dasarnya memiliki tujuan untuk membasmi serta mengurangi berbagai tekanan yang disebabkan oleh berbagai perubahan sosial ekonomi, serat dapat menghindari terjadinya sistem sosial yang buruk yang akan berdampak pada proses pembangunan serta membuat suatu kondisi dimana kondisi tersebut mampu mendorong meningkatnya kesejahteraan masyarakat. Pengertian reorganisasi memiliki ccakupan yang cukup luas serta dalam berkaitan dengan kegiatan yang diselenggarakan untuk memberkan pemulihan dan pemberian fungsi atau peranan baru.

\section{a) Fungsi penyembuhan (curative)}

Untuk melakukan pemulihan atau rehabilitasi yang dilakukan untuk penanaman serta menumbuhkan fungsi sosial, baik dalam dirinya sendiri maupun kelompok masyarakat umum. Program dari kesejahteraan sosial ialah melakukan penyembuhan apabila di dalamnya tercakup sekumpulan kegiatan yang diperuntukan untuk menguarangi keadaan-keadaan, ketidakmampuan fisik, emosional dan sosial agar orang yang mengalami masalah tersebut dapat berfungsi secara normal kembali di dalam masyarakat.

\section{b) Fungsi pencegahan (preventive)}

Kesejahteraan sosial yang memiliki sifat pencegahan yang diperuntukan untuk dapat memperkuat suatu kelompok, keluarga, serta kesatuan masyarakat untuk menegah timbulnya masalah atau kondisi sosial yang baru.

\section{c) Fungsi pengembangan (development)}

Kegiatan ini berfungsi untuk dapat mengembangkan berbagai tujuan serta orientasinya untuk memberikan sumbangan langsung bagi proses pembangunan. Tindakan yang dilakukan untuk berlangsungnya kesejahteraan suatu unsur pelaksanaan agar terjadinya suatu perubahan 
yaitu dalam meningkatkan proses perubahan sosial. Hal ini sangat berpengaruh terhadap perubahan struktur serta fungsi kelaurag maupun masyarakat, sehingga pesertanya disipkan untuk mendapatkan serta melaksanakan peran, fungsi dan tanggung jawab yang baru.

d) Fungsi penunjang (supportive)

Dalam hal ini mencakup berbagai kegiatan untuk membantu mewujudkan tujuan. Contohnya, untuk membantu terwujudnya tujuan kebijaksanaan pemerintah dalam memperkuat program kependudukan serta keluarga berencana dengan cara melalui motivasi yang diberikan serta sikap yang dilakukan oleh orang-orang baik itu kelompok, keluarga maupun masyarakat.

3) Timbulnya masalah kesejahteraan sosial.

Penyebab timbunya masalah sosial ini disebakan karena terjadinya beberapa hambatan, antara lain:

a) Sangat tergantung pada perekonomian

b) Tidak memiliki potensi untuk menyesuaikan diri

c) Disebabkan karena tingkat kesehatan yang rendah

d) Tidak adanya waktu luang dan sarana rekreasi.

e) Terbentuknya keadaan sosial serat pengolahan pelayanan sosial yang tidak efektif

Gibson (1994:31) mengemumukan arti dari efektivitas melalui dua pendekatan sistem, yakni:

1) Semua siklus input-proses-output, bukan hanya dilihat dari output saja, dan

2) Adanya feedback atau timbal bail yang diakibatkan oleh hubungan antara organisasi dengan lingkungan disekitarnya.

Sedangkan menurut menurut Siagian (2001:24), efektivitas dapat diartikan sebagai hasil dari sejumlah barang atas jasa kegiatan yang dilakukan yang merupakan pemanfaatan dari sumber daya sarana maupun prasana dalam jumlah tertentu yang secara sadar telah ditetapkan sebelumnya. Tercapai tidaknya suatu tujuan tertentu merupakan cerminan dari keberhasilan efektivitas. Jika kegiatan yang dilaksanakan sudah mendekati tujua, maka dapat disimpulkan semakin tinggi tingkat efektivitasnya. Efektivitas dapat diukur dari seberapa jauh tujuan serta efisiensi dapat dicapai, dengan mengkombinasikan sumber daya dnegan cermat. Atmosoeprapto (2002:139) memberikan arti bahwa efektivitas adalah melakukan hal yang benar. Budiani (2007: 53) mengemukakan efektivitas suatu program dapat diukur melalui berbagai variabel yakni seperti berikut:

a. Ketepatan program yakni mengukur sejauh mana peserta yang terhimun dalam prgram tersebut sudah mencapai tujuan atau sasaran yang telah ditentukan

b. Sosialisasi program merupakan potensi dari penyelenggara program dalam melaksanakan penyampaian suatu informasi mengenai program tersebut baik pada masyarakat luas dan khususnya bagi peserta program.

c. Pencapaian tujuan program, dapat diukur ketika antara hasil yang di dapat dengan tujuan yang ditentukan sudah sesuai atau seimbang. 
d. Pemantuan program ialah keberlangsungan kegiatan seetlah program dilaksanakan sebagai bentuk perhatian kepada peserta program.

Berdasarkan Undang-Undang Republik Indonesia No. 11 tahun 2009 tentang Kesejahteraan Sosial Bab I Pasal I ayat 8 menyatakan bahwa salah satu program pemerintah adalah rehabilitasi sosial. Rehabilitasi sosial adalah pengembangan bagaimana seseorang dapat menjalankan fungsinya secara layak atau wajar dalam kehidupan bermasyarakat. Lebih lanjut dalam pasal 7 ayat 1 Rehabilitasi sosial ini dapat diartikan untuk mengembalikan dan meningkatkan skill dari seseorang yang tidak berjalan sesuai dengan fungsi yang seharusnya dalam melaksanakan fungsi sosial selaknya kebanyakan orang.

Fenomena yang pada umumnya terjadi di kota besar, seperti gelandangan dan pengemis, disebabkan karena susahnya hidup yang mereka alami di pedesaan. Ini merupakan akibat dari peningkatan jumlah penduduk dan semakin berkurangnya tanah garapan. Sedangkan pada umumnya masyarakat yang hidup di desa merupakan masyarakat miskin. Hal ini mendorong mereka untuk mencari penghidupan di tempat lain untuk memperbaiki kehidupan mereka kedepannya, lalu pergi ke kota. Ketertarikan yang disebabkan oleh perkembangan pembangunan infrastruktur serta keadaan sosial ekonomi di kota besar yang sangat pesat, merupakan faktor pendorong berpindahnya masyrakat desa ke kota. Hal lain yang menjadi faktor pendorong perpindahan masyarakat desa ke kota ialah diperburuk oleh pembangunan yang lambat di pedesaan.

Data gelandangan dan pengemis tahun 2015 menurut dinas sosial provinsi jawa barat berturut turut adalah 5.800 dan 2.757. namun jumlah tersebut mengalami peningkatan ditahun 2017 yaitu sebesar 7.949 untuk gelandangan dan 15.400 untuk pengemis. Jumlah gelandangan dan pengemis di Jawa Barat sebagian besar berada di Kota Bandung, dikarenakan Bandung merupakan Ibu Kota Provinsi. Sehingga banyak masyarakat desa yang menjadi pengemis di Kota Bandung. Hal tersebut menunjukan bahwa adanya ketidaksesuain antara peraturan pemerintah provinsi Jawa Barat Nomor 10 tahun 2012 pasal 48 ayat 1 dan 2 tentang ketertiban sosial yang menyatakan bahwa ketertiban sosial dan fasilitas umum yang seharusnya bersih dari kegiatan pengumpulan uang atau barang di muka umum yang telah dijamin oleh Pemerintah Kabupaten Kota, namun yang tejadi, sangat bertentangan dengan peraturan perundang-undangan yang berlaku.

Gelandangan dan pengemis akan cenderung mengalami peningkatan, sebagai akibat dari kondisi sosial ekonomi yang mengakibatkan meningkatnya kemiskinan, pendidikan yang semakin rendah serta rasa aman oleh karena itu masalah gelandangan, pengemis harus ada penanganan yang serius baik oleh pemerintah maupun partisipasi dari masyarakat lainnya dengan suatu perencanaan yang berkesinambungan. Salah satunya yaitu melalui rehabilitasi sosial di tiap-tiap daerah provinsi termasuk Provinsi Jawa Barat yang mendominasi adanya gelandangan dan pengemis.

Rehabilitasi sosial Dinas Sosial Provinsi Jawa Barat dilakukan melalui Balai Rehabilitasi Sosial Bina Karya (BRSBK). Balai ini memberikan pelayanan serta rehabilitasi sosial untuk orang-orang yang mengalami masalah baik itu dalam aspek kesejahteraan sosial seperti gelandangn dan pengemis. Balai Rehabilitasi Sosial Bina Karya (BRSBK) Jawa Barat memiliki peran untuk dapat memperbaiki permasalahan yang terjadi pada gelandangan dan pengemis, setidaknya keterlibatan dalam pembangunan, minimal untuk keluarga dan diri sendiri. Namun 
pada kenyataannya masih banyak para gelandangan dan pengemis yang sudah dibina dan direhab di BRSBK kemballi lagi ke sudut Kota Jawa Barat.

Orang miskin dan PMKS ialah kelompok yang sering kali tersisihkan, hal ini dikarenakan kehidupan mereka tidak terjamah oleh strategi pembangunan dimanan mekanisme pasar dijaikan sebagai tumpuan. Rentannya kelompok ini, disebakan karena kecacatan fisiknya atau penyandang disabilitas serta pengangguran yang kurang mampun merespon perubahan sosial yang terjadi disekitarnya, dimana hal ini mengakibatkan kelompok ini makin tidak terlihat dan tersisihkan.

Pemerintah Provinsi Jawa Barat dalam hal ini Dinas Sosial Provinsi Jawa Barat melalui Balai Bina Karya dalam menuntas masalah kemiskinan dalam kategori Gepeng mempunyai program-program sebagai berikut:

Tabel 1.1

Program-program Rehabilitasi Sosial BRSBK

\begin{tabular}{|c|l|l|}
\hline No & \multicolumn{1}{|c|}{$\begin{array}{c}\text { Program-Program } \\
\text { Rehabilitasi }\end{array}$} & \multicolumn{1}{c|}{ Output } \\
\hline 1 & $\begin{array}{l}\text { Bimbingan Fisik, } \\
\text { Mental,Dan Spiritual }\end{array}$ & $\begin{array}{l}\text { Bimbingan fisik, mental, dan spiritual bertujuan untuk } \\
\text { membangun konsep diri yang positif dan percaya diri. }\end{array}$ \\
\hline 2 & $\begin{array}{l}\text { Bimbingan Sosial } \\
\text { Perorangan }\end{array}$ & $\begin{array}{l}\text { Bimbingan sosial perorangan bertujuan untuk } \\
\text { membantu individu agar klien mampu menyesuaikan } \\
\text { diri dengan lingkungan sosialnya. }\end{array}$ \\
\hline 3 & $\begin{array}{l}\text { Bimbingan Sosial } \\
\text { Kelompok }\end{array}$ & $\begin{array}{l}\text { Bimbingan sosial kelompok bertujuan untuk } \\
\text { mengurangi permasalahan yan terjadi pada klien melaui } \\
\text { cara pemanfaatan dinamika kelompok. }\end{array}$ \\
\hline 4 & $\begin{array}{l}\text { Bimbingan keterampilan } \\
\text { dan kewirahusaan } \\
\text { pengolahan bahan } \\
\text { jual } \\
\text { b. keterampilan menjahit } \\
\text { c. } \begin{array}{l}\text { Keterampilan montir } \\
\text { motor } \\
\text { d. Keterampilan tambahan } \\
\text { berupa bercocok tanam } \\
\text { dan kerajinan tangan }\end{array}\end{array}$ & $\begin{array}{l}\text { a. } \begin{array}{l}\text { Pengolahan bahan pangan agar para gepeng mampu } \\
\text { membuat bahan olahan pangan yang layak dijadikan } \\
\text { peluang usaha. } \\
\text { keterampilan menjahit dimaksudkanagar gepeng } \\
\text { memiliki keterampilan dan peluang usaha kecil } \\
\text { kecilan. }\end{array} \\
\text { c. } \begin{array}{l}\text { keterampilan montir motor dimaksudkan agar para } \\
\text { gepeng dapat memahami prihal otomotif sehingga } \\
\text { memiliki keterampialn dan pekrjaan layak. } \\
\text { keterampilan pertanian agar para gepeng bisa } \\
\text { bercocok tanam. } \\
\text { keterampilan Handycraft dimaksudkan para gepeng } \\
\text { memilik kerajinan tangan di diri masing masing }\end{array}\end{array}$ \\
\hline
\end{tabular}

Sumber: Balai Rehabilitasi Sosial Bina Karya Jawa Barat

Program yang dilaksanakan oleh Balai Rehabilitasi Bina Karya dimaksudkan agar dampak yang dihasilkan dapat mencegah gepeng tidak kembali ke jalanan karena dalam pelaksanaan para gepeng telah diberikan rehabilitasi berupa keterampilan dan spiritual yang cukup dan bertujuan mengubah pola pikir kerah yang tentunya lebih baik. Pada observasi awal, peneliti mendapatkan pengakuan dari seorang mahasiswa yang magang disana, mahasiswa tersebut mengakui kalau para gepeng telah mengikuti berbagai program rehabilitasi yang diberikan oleh Balai Bina Karya, tetapi 
masih banyak yang kembali ke jalanan ibu kota, dan mengganggap pendapatan mengemis lebih menjanjikan dari pada berwirausaha. Dengan demikian, penelitian ini bertujuan untuk menganalisis efektivitas program rehabilitasi sosial terhadap gelandangan dan pengemis di Balai Rehabilitasi Sosial Bina Karya Cisarua.

\section{Metode Penelitian}

Metode yang digunakan dalam penelitian ini adalah metode deskriptif dengan pendekatan kualitatif. Metode deskriptif bertujuan untuk medeskripsikan atau memberi suatu gambaran secara lengkap terhadap efektivitas program rehabilitasi sosial Balai Rehabilitasi Sosial Bina Karya. Metode penelitian ini menggunakan penelitian dengan pendekatan kualitatif karena pendekatan kualitatif merupakan penelitian yang menghasilkan ide-ide, aspirasi yang tidak menghasilkan angka tetapi berupa deskripsi dalam bentuk kata dan analisis.

\section{Hasil Dan Pembahasan}

Upaya pembangunan bidang Kesejahteraan Sosial termasuk peningkatan Kesejahteraan Sosial yang diperuntukan bagi orang-orang jalanan, pengemis, korban perdagangan manusia, gelandangan, serta orang-orang yang berada di kolong jembatan merupakan bagian integral dari pembangunan Nasional yang mengupayakan agar tidak seorangpun tertinggal dan tidak terjangkau dalam proses pembangunan. Sebagai manusia mereka pada hakikatnya memiliki kemampuan diri yang dapat dikembangkan, namun untuk mengembangkan kemampuan tersebut perlu adanya proses khusus yaitu melalui pelayanan rehabilitasi sosial diselenggarakan untuk orang-orang jalanan, pengemis, korban perdagangan manusia, gelandangan, serta orag-orang yang berada di kolong. Undang Undang Dasar 1945 pasal 27 ayat (2) menyatakan bahwa: "Tiap - Tiap Warga Negara Berhak Atas Pekerjaan Dan Penghidupan Yang Layak Bagi Kemanusiaan”. Demikian pula pasal 34 bahwa: "Fakir Miskin Dan Anak Terlantar Dipelihara Oleh Negara". Setiap warga negara dalam pengertian tersebut di atas termasuk bagi orang-orang yang mengalami disfungsi sosial yang disebabkan oleh berbagai macam faktor baik karena kemiskinan, kecacatan, keterlantaran, ketunaan sosial, korban bencana dan pengungsi, keterpencilan, eksploitasi, korban tindak kekerasan dan disintegrasi. Untuk dapat memperoleh kehidupan dan penghidupan yang layak serta mewujudkan kesejahteraan sosialnya, maka Pemerintah berkewajiban mengupayakan fasilitas fasilitas yang diperlukan dalam rangka peningkatan sumber daya manusia menuju pembangunan manusia seutuhnya. Salah satu upaya yang dilaksanakan oleh Pemerintah dalam rangka penyediaan fasilitas bagi pelayanan sosial adalah dilaksanakan melalui sistem Panti.

\section{Pelaksanaan Pembinaan Gelandangan dan Pengemis BRSBK}

Proses penanganan yang diselenggarakan oleh Balai Rehabilitasi Sosial Bina Karya ini adalah pembinaan berupa bantuan pertolongan, bimbingan, perawatan serta rehabilitas dimana kegiatan berlangsung secara terstruktur, jelas arah tujuannya, serta diremcanakan dengan baik dengan dasar pendekatan pekerjaan sosial yang diperuntukan untuk agar dapat meningkatnya 
kesejahteraan sosial para pengemis tersebut. Dibawah, penulis sajikan bagan pola operasional pengangan Keluarga Binaan Sosial (KBS) Balai Rehabilitasi Sosial Bina Karya Cisarua Provinsi Jawa Barat.

\section{Gambar 4.1}

\section{Pola Operasional Pengangan Keluarga Binaan Sosial (KBS) Balai Rehabilitasi Sosial Bina Karya Cisarua Provinsi Jawa Barat}

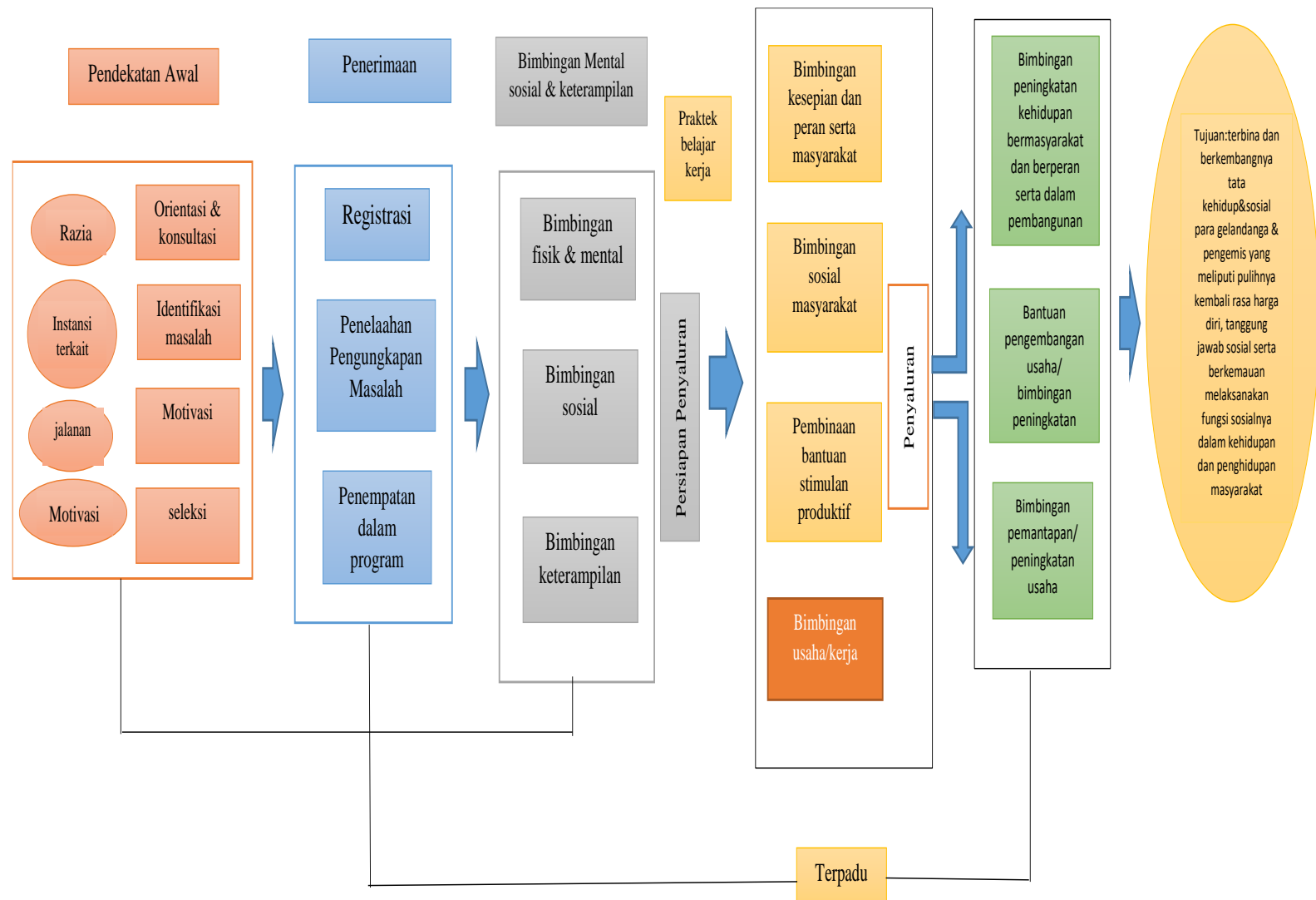

Adapun pola operasional dalam meningkatkan kesejahteraan sosial di Balai Rehabilitasi Sosial Bina Karya ini dilaksanakan selama 4 bulan per angkatan mulai dari klien masuk sampai berakhirnya waktu yang sudah ditetapkan. Untuk terciptanya ketertiban pelayanan kesejahteraan tersebut, maka pihak balai melakukan tahap-tahap proses pelayanan berdasarkan pada buku acuan (pedoman) yang dikeluarkan oleh Dinas Sosial yang diantaranya sebagai berikut:

\section{a. Pendekatan Awal}

Tahap pendekatan ini adalah serangkaian kegiatan yang dilakukan guna untuk memperkenalkan segala sesuatu yang ada di Balai.

1) Sosialisasi 
Sosialisasi dilaksanakan dalam rangka menyampaikan informasi tentang program dan kegiatan balai rehabilitasi sosial bina karya kepada Dinas Sosial Kota dan Kabupaten dengan maksud agar kegiatan pelayanan rehabilitasi sosial gelandangan mendapatkan informasi dan jadwal pembinaan yang dilaksanakan oleh Balai.

2) Identifikasi, Seleksi, dan Motivasi

Pelaksanaan kegiatan seleksi, identifikasi, dan motivasi awal bagi calon warga binaan dilakukan oleh Dinas Sosial Kota dan Kabupaten. Hasil dari seleksi, identifikasi, dan motivasi calon warga binaan selanjutnya dikirim ke Balai oleh Dinas Sosial Kota Kabupaten. Calon warga binaan yang dikirim dari dinas sosial kota dan kabupaten selanjutnya diseleksi ulang oleh para pekerja sosial dan seksi penerimaan dan penyaluran di balai untuk memeriksa kesesuaian calon warga binaan dengan kriteria yang telah ditentukan.

b. Penerimaan

Registrasi sebelum calon klien masuk kedalam balai dan mengikuti seluruh program, terlebih dahulu klien harus memberi data-data pribadi seperti ktp dan kk atau surat keterangan dari Dinas Sosial masing-masing.

1) Penelaah dan pengungkapan masalah

a) Faktor yang menentukan pengaruh signifikan terhadap penyebab berlangsungnya keadaan yang dialami oleh para gelandangan dan pengemis beserta keluarganya pada saat ini.

b) faktor penentu lainnya yang paling kritis, keterkaitan antara pemahaman dengan memilih faktor-faktor yang dapat diatasi dan menentuan sumber, tersedianya motivasi serta kekuatan.

c) Pengkajian kembali dapat dilakukan setelah dilakukannya pengujian serta penyusunan instrumen yang telah tersusun, para profesional yang terlibat didalamnya, antara lain tes kemampuan, tes psiko sosial, catatan kasus, tes penyesuaian sosial dan lain-lain.

2) Tahap Resosialisasi

Mental sosial dan keterampilan kegiatan ini bertujuan untuk menumbuhkan pengertian, kepedulian serta kemauan masyarakat untuk ikut berperan dalam melaksanakan pembinaan kesejahteraan sosial bagi para pengemis dan gelandangan dan bimbingan ini dilakukan untuk penyiapan tempat penyaluran sesuai dengan keterampilan dari masing-masing klien.

a) Bimbingan Sosial Hidup Bermasyarakat

Bimbingan sosial ini merupakan proses yang utama, karena pada bagian ini merupakan tahap peringanan beban dari sebuah Balai dalam kegiatan yang bertujuan untuk mempersiapkan para gelandangan dan pengemis, untuk kembali ke masyarakat.

\section{b) Bimbingan Usaha Kerja Produktif}

Bimbingan ini dilakukan untuk penyiapan tempat penyaluran kerja/usaha/transmigrasi para klien setelah menerima bimbingan/pembinaan rehabilitasi selama berada di dalam Balai. 


\section{3) Tahap Penyaluran}

Tahapan ini bertujuan untuk menempatkan klien pada lapangan kerja atau sektor usaha sesuai dengan bakat dan keterampilan yang dimiliki. Jenis penyaluran berupa penyaluran ke lapangan kerja/usaha, kembali kekeluarga/daerah asal, ataupun mengikuti program transmigrasi berwirausaha.

\section{4) Tahap Bimbingan Lanjut}

Rancangan yang dilakukan dalam tahap ini melakukan kegiatan bimbingan yang dilakukan untuk memantau perkembangan bekas klien guna memantapkan, meningkatkan dan mengembangkan kemandirian klien. Kegiatan ini dilakukan oleh beberapa pihak terkait yang bekerjasama dengan pihak balai terkait.

Jadwal pembinaan gelandangan dan pengemis pelaksanaan program yang berada di Balai Rehabilitasi Sosial Bina Karya ini yakni dilaksanakan rutin yakni dari hari Senin sampai Minggu, dimulai dari pukul 05.15 sampai 21.00 WIB. Adapun pelaksanaannya diselenggrakan oleh aparatur sosial atau pekerja kesejahteraan sosial serta tenaga teknis lainnya seperti psikolog, guru, dokter, tenaga instruktur serta para petugas dari lembaga/instansi terkait lainnya.

2. Pengawasan Yang Dilakukan Oleh BRSBK Terhadapat Gelandangan Dan Pengemis Yang Telah Mendapatkan Pembinaan

Pengawasan kepada gelandangan dan pengemis setelah melaksakanan program adalah salah satu bentuk yang dilakukan oleh balai agar kita dapat menetapkan tujuan supaya terealisasi dengan baik dan untuk memastikan bahwa para gelandangan dan pengemis tidak turun lagi ke jalan dan memberikan suatu bantuan berupa usaha yang diberikan kepada mereka. Pengawasan dilakukan oleh aparatur atau pegawai balai langsung turun ke lapangan dimana mereka menjalankan usaha baru mereka, apakah mengalami kemajuan yang signifikan atau tidak.

Berdasarkan wawancara dapat disimpulkan bahwa pengawasan yang dilakukan setelah program dilaksanakan oleh balai sudah mengalami progres yan cukup baik dengan melakukan pengawasan serta memberikan suatu bantuan berupa usaha-usaha yang dijalankan oleh mereka, sehingga mereka dapat mengembangkan usahanya sendiri setelah dilakukannya pemberdayaan, agar mereka tidak terjun kembali kejalan.

\section{Analisis SWOT}

Kekuatan yang berada di program Balai Rehabilitasi Sosial Bina Karya ini, dalam mengefektivitaskan program rehabilitasi terhadap pengemis, gelandangan, tidak menutup kemungkinan adanya sejumlah faktor pendukung dan faktor penghambat. Pada dasarnya, para pengemis yang dibina di balai ini mempunyai potensi tersendiri yang kemudian mereka ini memiliki keinginan yang kuat untuk mengembangkan minat dan bakatnya tersebut dalam menghadapi segala permasalahan yang akan terjadi dalam kehidupannya. Terciptanya jalinan sikap kekeluargaan dan kebersamaan antara pengurus dan para pengemis yang menjadi klien di balai sehingga dalam melaksanakan pembinaan tersebut menimbulkan adanya pendekatan secara emosional, saling percaya dan saling bertanggung jawab antara keduanya. Yang paling mendukung lancarnya pelaksanaan program adalah dengan adanya semangat serta keinginan yang 
kuat dari para klien dalam mengikuti pembinaan/bimbingan tersebut, diantaranya berupa bimbingan motivasi, bimbingan keagamaan, bimbingan keterampilan, dan sebagainya.

Kelemahan yang dijumpai dalam pelaksanaan program, terhadap gelandangan dan pengemis. Kurangnya anggaran yang diberikan oleh pemerintah setempat sehingga menghambat pelaksanaan program. Tingkat pendidikan yang rendah menyebabkan beberapa materi yang disampaikan sangat lamban untuk diterima oleh gelandangan dan pengemis. Waktu pembinaan yang dirasa terlalu singkat, yang bila tidak dimanfaatkan dengan baik maka akan mengakibatkan ketidaksungguhan dan ketidakseriusan terhadap materi yang akan didapat oleh para klien. Atau bahkan dirasa tidak cukup untuk merubah secara total segala pola tingkah laku para pengemis yang sudah terbiasa dengan kehidupan jalanan yang berlatar belakang tidak mengindahkan tata kemasyarakatan, sehingga dikhawatirkan mereka bisa kembali lagi melakukan aktivitasnya sebagai penyandang masalah kesejahteraan sosial. Kurangnya sarana dan prasarana yang memadai sehingga menghambat jalannya suatu program. Seperti ruang kelas, tempat tinggal klien yang kurang layak dan terbatasnya sumber air yang bersih dan tidak fokusnya klien yang sedang mengikuti program karena membawa anak anaknya kekelas. Kurangnya pemantauan ketempat tinggal klien oleh pekerja sosial sehingga banyak klien yang bisa saja keluar tanpa seijin pekerja social dan kurangnya sumber daya manusia yang berkualitas.

Peluang keberhasilan program yaitu dengan memberikan modal kepada klien yang telah menyelesaikan masa program, bekal tersebut merupakan salah satu peluang agar para klien dapat mandiri dan memulai usaha dengan menerapkan ilmu ilmu yang didapatkan dibalai rehabilitasi, sehingga mereka tidak kembali lagi kejalanan. Hal tersebut akan mengurangi angka gelandangan dan pengemis di Provinsi Jawa Barat. Ancaman yang mungkin terjadi diantaranya adalah para klien yang telah mendapatkan program rehabilitasi kembali kejalanan, hal tersebut dikarenakan para klien yang kembali kejalanan tidak memiliki tempat tinggal tetap, dan pihak balai tidak memberikan modal yang cukup untuk membuat usaha sehingga mereka berpikir bahwa biaya hidup dijalan lebih murah dibandingkan dengan biaya sewa rumah dan tempat usaha. Sehingga pada akhirnya mereka lebih memilih untuk kembali kejalanan. Hal ini menjadi ancaman bagi pemerintah khususnya dinas sosial Provinsi Jawa Barat dan Balai Rehabilitasi Sosial Bina Karya agar melakukan evaluasi terhadap program rehabilitasi sosial sehingga ancaman tersebut dapat teratasi.

\section{Simpulan}

Dalam penyelenggaraan pembinaan yang dilaksanakan terhadap para gelandangan dan pengemis adalah berupa pelayanan dan rehabilitasi. Diantaranya dilakukan melalui berbagai kegiatan bimbingan, baik berupa bimbingan spiritual, fisik, sosial, mental maupun bimbingan keterampilan. Pada dasarnya, pembinaan yang dilaksanakan di BRSBK tersebut tidak lain bertujuan tujuan dari dilaksanakannya program tersebut dapat diistilahkan dengan "Me-manusia-kan Manusia". Dimana program tersebut diantaranya ditujukan untuk mencegah agar tidak adanya gelandangan dan pengemis didalam masyarakat, mengurangi meningkatnya jumlah gelandangan dan pengemis di masyarakat, hidup bermasyarakat kembali bekas gelandangan dan pengemis agar menjadi bagian dari masyarakat yang mempunyai kemampuan guna mendapat hidup yang lebih baik, kehidupan yang semestinya sejajar dengan kebanyak orang lainnya. 


\section{Referensi}

Anggara, S. (2012). Ilmu Administrasi Negara. Bandung: CV Pustaka Setia.

Atmosoeprapto, K. (2002). Menuju SDM Berdaya - Dengan Kepemimpinan Efektif dan Manajemen Efisien. PT. Alex Media Komputindo: Jakarta.

Dimock \& Dimock. (1992). Administrasi Negara. Jakarta: Rineka Cipta.

Effendy, O.U. (2003). Ilmu, Teori dan Filsafat Komunikasi. Bandung: Citra Aditya Bakti.

Etzioni, A. (1982). Organisasi-Organisasi Modern. Alih bahasa oleh Suryatim. Jakarta: Diterbitkan atas kerja sama Universitas Indonesia dan Pustaka Bradjaguna.

Fahrudin, A.D. (2012). Pengantar Kesejahteraan Sosial. Bandung: PT revika Aditama.

Gibson, dkk. (1994). Organisasi dan Manajemen Perilaku Struktur Proses. (Terjemahan: Djoerban Wahid). Jakarta: Penerbit Erlangga

Hariwoeryanto, K. (1987). Kebijaksanaan Sosial dan Evaluasi Kesejahteraan Sosial. Bandung: PT. Karya Nusantara

Meleong, L.J. (2001). Metodologi Penelitian Kualitatif. Bandung: Remaja Rosdakarya.

Nasution. S. (2000). Metodologi Penelitian Naturalistik Kualitatif. Bandung: Taristo.

Ndraha, T. (2005). Teori Budaya Organisasi. PT. Rineka Cipta, Jakarta.

Nurdin, M.F. (1990). Pengantar Studi Kesejahteraan Sosial. Bandung: Angkasa Bandung.

Undang-Undang Republik Indonesia No. 11 tahun 2009 tentang Kesejahteraan sosial.

Undang- Undang Dasar 1945 Pasal 34 Fakir Miskin dan Anak Terlantar dipelihara oleh Negara.

Peraturan pemerintah republik Indonesia nomor 31 tahun 1980 tentang penganggulangan gelandangan dan pengemis Bab 1 pasal 1 ayat 1 dan 2.

Peraturan Daerah Provinsi Jawa Barat Nomor 10 Tahun 2012 tentang Penyelenggaraan Sosial.

Peraturan Gubernur Jawa Barat Nomor 113 tahun 2009 tentang Organisasi dan Tata Kerja Unit Pelaksana Teknis Dinas dan Badan di Lingkungan Pemerintah Provinsi Jawa Barat.

Peraturan Pemerintah Republik Indonesia (PP) No 31 tahun 1980 tentang Penanggulangan Gelandangan dan Pengemis.

Siagian, S.P. (1986). Organisasi, Kepemimpinan dan Perilaku Organisasi. Jakarta: Penerbit Gunung Agung.

Sihombing, M.J. (2005). Kekerasan Terhadap Masyarakat Marjinal. Yogyakarta: Narasi.

Steers, R.M. (1985). Efektivitas Organisasi (penerjemah Magdalena Jamin). Jakarta: Penerbit Erlangga.

Stoner, J. (1984). Manajemen. Intermedia: Jakarta.

Sugiono. (2007). Metode Penelitian Penelitian Pendidikan Pendekatan Kualitatif, dan R\&D. Bandung: Alfabeta. 
Suharto, E. (2010). Analisis Kebijakan Publik Panduan Praktis Mengkaji Masalah Dan Kebijakan Sosial. Bandung: CV alphabet.

Sumaryadi, I.N. (2005). Perencanaan Pembangunan Daerah Otonom dan Pemberdayaan Masyarakat. Jakarta: Penerbit Citra Utama

Tangkilisan, H.N.S. (2005). Manajemen Publik. Jakarta: Penerbit Grasindo

Ulbert, S. (2012). Metode Penelitian Sosial. Bandung: Refika Aditama

Waldo, D. (1996). Pengantar Studi Public Administration. Jakarta: Bumi Aksara. 